Ковшун Н. Е. [1; ORCID ID: 0000-0003-0573-2932], д.е.н., професор,

П'ятка Н. С. [2; ORCID ID: 0000-0001-9810-3961], к.е.н., ст. викладач

Жидик I. A. ${ }^{[1 ; 0 R C I D ~ I D: 0000-0002-8438-9708], ~}$ заступник директора Інституту післядипломної освіти з навчальнометодичної роботи

${ }^{1}$ Національний університет водного господарства та природокористування, м. Рівне ${ }^{2}$ Мукачівський державний університет, м. Мукачево

\title{
ЕФЕКТИВНІСТЬ ЕКОЛОГІЧНОГО ІНВЕСТУВАННЯ В УКРАЇНІ
}

В статті визначено зміст екологічних інвестицій та виділено їх характерні ознаки. Із врахуванням основних напрямів здійснення екологічного інвестування представлено семантичну модель взаємодії між його об'єктами та суб'єктами. Висвітлено результати дослідження основних напрямів фінансування природоохоронної діяльності В Україні. Встановлено тренди зміни номінального та реального обсягів капітальних інвестицій на охорону навколишнього природного середовища. Проведене ретроспективне дослідження їх складових. Визнано низьким рівень інвестиційного забезпечення охорони навколишнього середовища в Україні. Показано актуальність проблеми адекватної оцінки доцільності та ефективності екологічних інвестицій.

3 урахуванням наукових розробок міжнародних організацій та провідних аналітичних центрів світу, розроблено пропозиції щодо методики оцінювання ефективності екологічного інвестування. Виділено етапи та рівні такого оцінювання. В результаті апробації запропонованого методичного підходу встановлено динаміку інтегрального індексу ефективності екологічного інвестування в Украйні в цілому та у регіональному розрізі.

Ключові слова: екологічні інвестиції; ефективність; фінансування екологічних інвестицій; критерій ефективності; методичний підхід; інтегральний показник; Україна.

Проблема залучення інвестицій до економіки України на даний момент вирішується в умовах, коли попит на інвестиції значно перевищує їх пропозицію. При практично повній відсутності власних засобів нині гостро стоїть питання розвитку провідних ланок економіки, для здійснення екологізації виробництва, переходу до «зеленої» економіки. В умовах дефіциту власних джерел 30 
фінансування українська економіка відчуває потребу в інвестиціях, які будуть одним 3 найвагоміших засобів для досягнення сталого соціально-економічного зростання, технологічного переоснащення та екологізації виробництва.

Чинна вітчизняна реформа децентралізації та Угода про асоціацію між Україною та Європейським Союзом (ЄC) створюють можливості і стимули для здійснення реформи системи управління охороною довкілля в Україні. Здатність ефективно вирішувати екологічні пріоритети країни сприятиме досягненню цілей економічного зростання і розвитку на екологічно стійкій основі. Здатність України відповідати вимогам міжнародних фінансових інститутів щодо екологічних і соціальних гарантій підвищить інвестиційну привабливість країни.

В процесі інтеграції України в ЄС для країни має бути пріоритетною загальноєвропейська мета у екологічній сфері зменшення усіх негативних впливів на довкілля та збільшення витрат на екологізацію економіки. Світова практика свідчить про високу ефективність інвестицій у природоохоронні проєкти, адже економічний ефект від відвернутої шкоди 10-15 разів перевищує обсяги вкладень.

Для відродження економіки України потрібні інтенсивні вкладення капіталу саме в екологічно спрямовані інновації, які можуть забезпечити не тільки економічний, але й екологічний та соціальний ефекти. За цих умов великого значення набуває проблема ефективності розподілу наявних коштів природоохоронного призначення, забезпечення отримання максимального ефекту при мінімально можливих фінансових витратах.

Вагомий внесок у розвиток теоретико-методичних засад та розроблення практичних рекомендацій щодо екологічного інвестування зробило чимало вітчизняних та зарубіжних вчених. Так, дослідженню сутності екологічних інвестицій, їх класифікації, принципів та напрямів реалізації екологічного інвестування присвячені праці А. Ігнатченко [1], О. Чигрин [2], В. Тихенко [3]. Проблема аналізу умов створення привабливого інвестиційного середовища для залучення екологічних інвестицій висвітлена в роботах І. Варламової [4] та О. Квактуна [5]. Праці П. Скрипчука [6] та 0. Латишевої [7] присвячені екологізації інноваційної та інвестиційної діяльності відповідно до вимог сталого розвитку суспільства. В. Голян [8] та І. Петренко [9] досліджують фінансове забезпечення природоохоронної діяльності, акцентуючи увагу на державній фінансовій підтримці охорони навколишнього природного середовища. У працях Л.Ліпич [10] та інших [11] досліджуються 
підходи до оцінювання ефективності екологічних інвестицій.

Розглянуті напрацювання науковців $\epsilon$ підґрунтям для подальших досліджень широкого спектру особливостей фінансування у сфері природоохоронної діяльності, зокрема вкрай актуальним $\epsilon$ дослідження його сучасного стану, а особливо оцінювання ефективності здійснення екологічного інвестування.

Метою статті $\epsilon$ висвітлення методико-прикладних положень щодо оцінювання ефективності екологічного інвестування в умовах децентралізації та інтеграції України в ЄС.

Теоретичні та практичні аспекти екологічних інвестицій відображено у багатьох працях вітчизняних та зарубіжних науковців. Загалом можна зазначити, що автори розглядають сутність поняття «інвестиції» або у широкому та вузькому значенні. Як правило, у широкому значенні під поняттям «інвестиції» розуміють - вкладення капіталу в усіх можливих формах 3 метою забезпечення його зростання в майбутньому періоді, отримання поточного прибутку або вирішення певних економічних та позаекономічних завдань; а у вузькому ж - забезпечення певного приросту капіталу. Розбіжність авторських трактувань сутності поняття «інвестиції» свідчать про те, що й досі відсутнє не тільки єдине визначення, а й автори виділяють різні підходи до визначення сутності даного поняття.

Проведений аналіз дозволив сформулювати власне розуміння теоретичного змісту поняття «екологічні інвестиції», суть якого зводиться до наступного: по-перше, цільова та функціональна характеристика екологічних інвестицій $є$ багатовекторною; по-друге, екологічні інвестиції слід розглядати як можливість запобігання негативному впливу на довкілля [12]. На підставі трактування сутності екологічних інвестицій, виділення їх характерних ознак, а також із врахуванням основних напрямів здійснення екологічного інвестування взаємодію між об'єктами, суб'єктами екологічного інвестування можна представити за допомогою семантичної моделі (рис. 1).

Дослідження основних напрямів фінансування природоохоронної діяльності в Україні свідчить, що найбільша частка в структурі сукупних коштів, що виділялися на здійснення природоохоронних заходів в Україні в 2018 рр., припадає на поточні витрати - 70,71\% загального обсягу фінансування. Капітальні інвестиції становлять у середньому лише третину всіх природоохоронних витрат, що не сприяє формуванню ресурсної бази модернізації, реконструкції та технічного переоснащення об'єктів природоохоронної інфраструктури. Встановлено, що тренди зміни номінального та реального обсягів капітальних інвестицій на охорону навколишнього природного середовища співпадають, проте в динаміці обсягів капітальних інвестиції на охорону навколишнього 32 

окресленого висхідного тренду не спостерігається, що свідчить про відсутність проявів реального збільшення екологічних інвестицій.

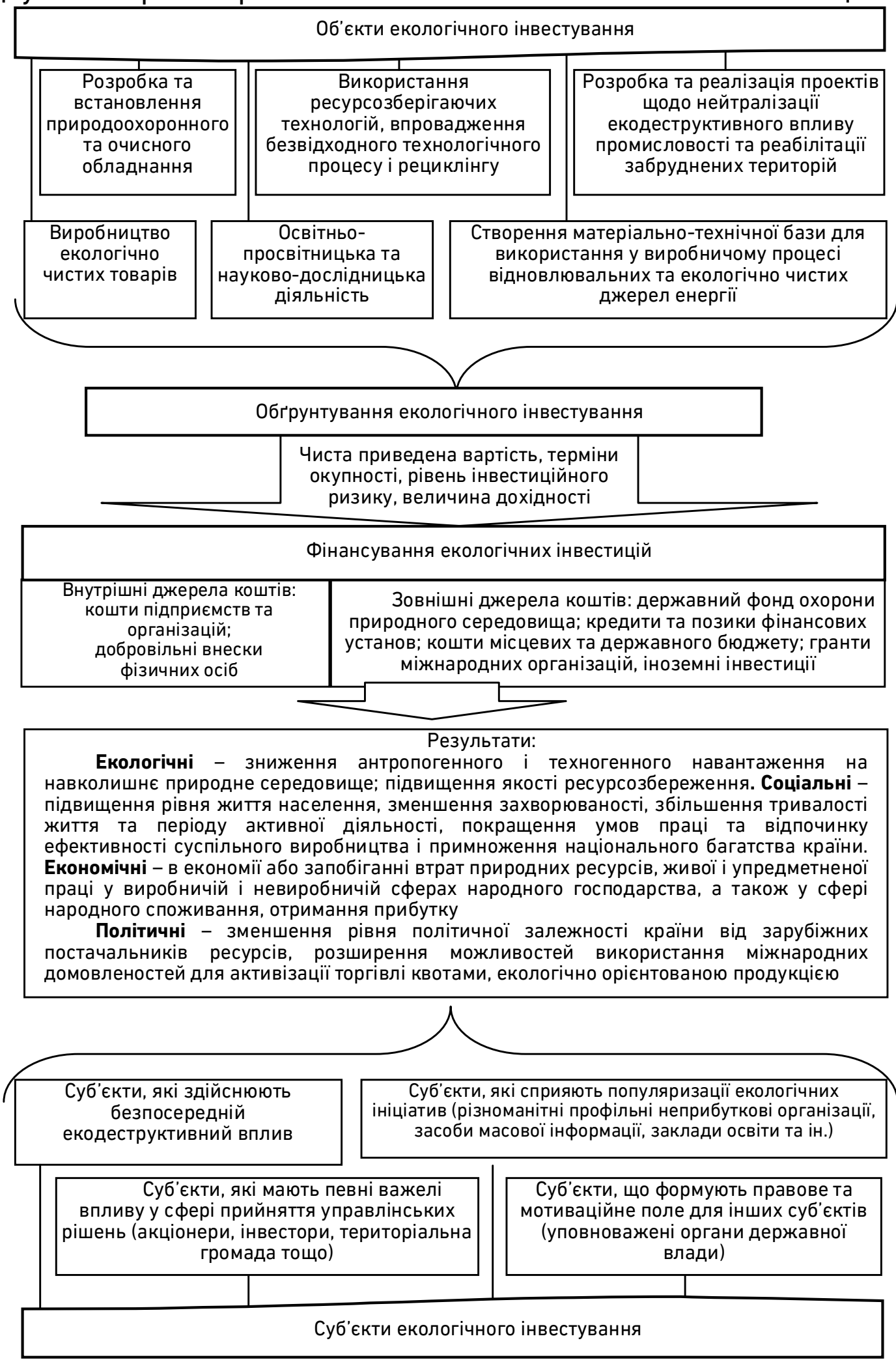

Рис. 1. Семантична модель процесу екологічного інвестування 
Проведене ретроспективне дослідження складових капітальних інвестицій на охорону навколишнього середовища України дозволило встановити, що у загальному обсязі екологічних інвестицій України лише 36,67\% становлять інвестиції в інтегровані технології, натомість в очищення - 58,73\% та інші види діяльності $4,60 \%$.

Отже, інвестиційне забезпечення охорони навколишнього середовища в Україні перебуває на низькому рівні, а виявлені обсяги інвестицій в інтегровані технології не сприяють формуванню ресурсної бази модернізації, реконструкції та технічного переоснащення об'єктів природоохоронної інфраструктури й може призвести до незворотних негативних впливів, адже інвестиційні витрати в інтегровані технології - це інвестиції, які призводять не лише до скорочення забруднення, а забезпечують також зміну технології чи модифікацію виробничого процесу. Підтвердженням даної тези слугує виявлений в результаті аналізу незначний темп зменшення забруднення навколишнього природного середовища, що в свою чергу не сприяє нарощенню природно-ресурсного потенціалу.

Зазначимо, що в Україні основними джерелами фінансування витрат на охорону навколишнього природного середовища виступають власні кошти підприємств, установ, організацій та кошти державного та місцевих бюджетів. Через відсутність належного інституціонального підґрунтя для залучення приватного капіталу у фінансування природоохоронної діяльності частка інших джерел $€$ незначною [13].

На нашу думку, виявлена обмеженість джерел фінансування спричинена надмірною одержавленістю та централізованістю системи управління природоохоронною діяльністю. Це призводить до зниження ефективності управління природокористуванням в регіонах, зокрема в процесі планування та використання екологічних інвестицій. Притаманна екологічній політиці України відомча спрямованість не сприяє повноті урахування інтересів окремих територій в створенні екологічно безпечного довкілля. В даному аспекті актуалізується проблема адекватної оцінки доцільності та ефективності інвестицій.

3 врахуванням наукових розробок міжнародних організацій та провідних аналітичних центрів світу, нами розроблено схематичну модель оцінювання рівня ефективності екологічного інвестування (рис. 2). Ієрархічна система показників ефективності екологічного інвестування відображає особливості запропонованого методичного підходу. 

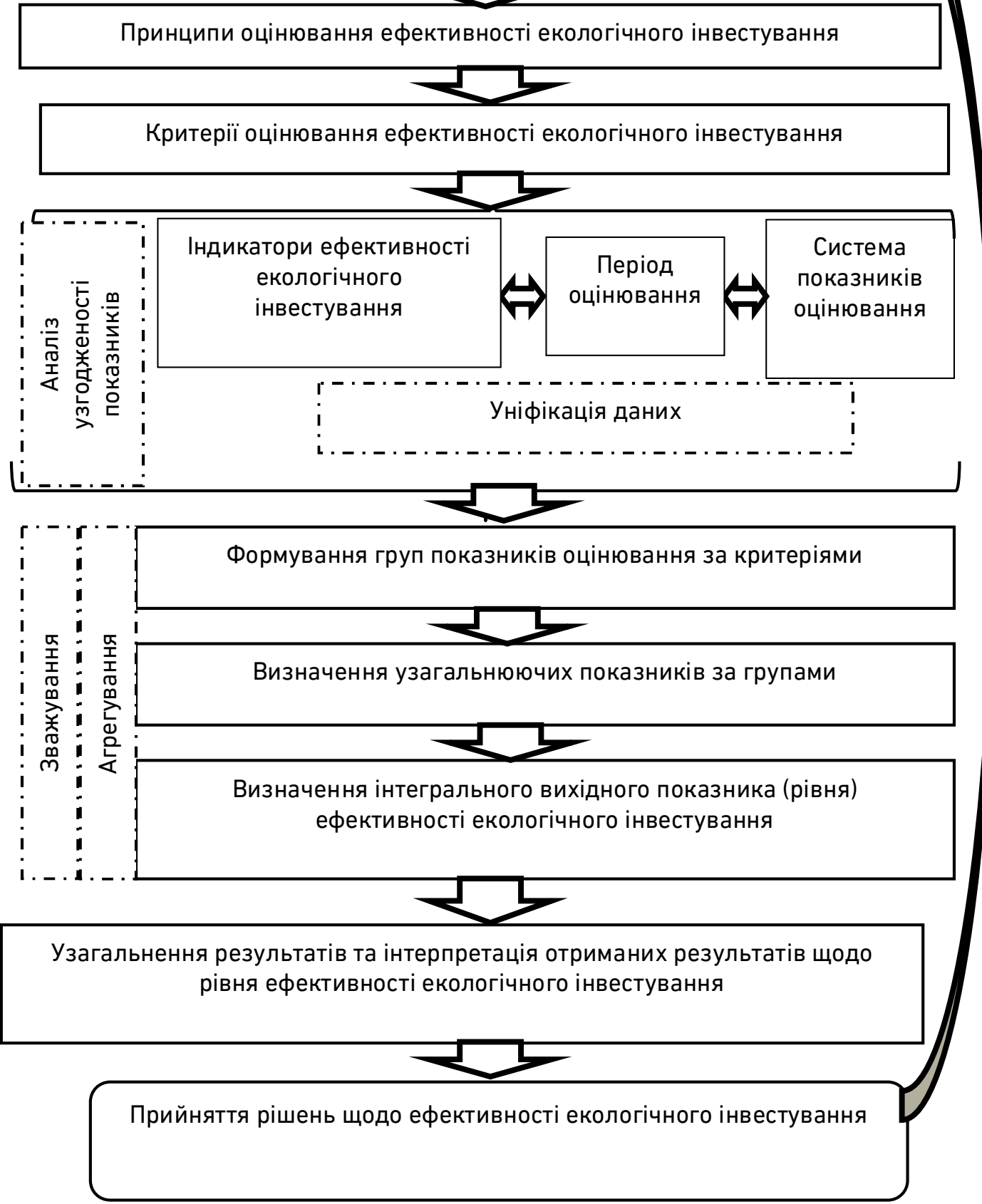

Рис. 2. Схематична модель оцінювання ефективності екологічного інвестування

Процес оцінювання ефективності екологічного інвестування $€$ складним та багатоетапним і передбачає агрегування даних на трьох рівнях: I рівень - для кожної складової відповідного індикатора; 
II рівень - для кожного критерію за агрегуванням значень відповідних індикаторів; III рівень - для інтегрального індексу. Це дозволяє здійснювати інтерпретацію результатів на основі бінарного підходу за допомогою єдиного критерію ефективності екологічного інвестування.

Нами виділено два основних критерії оцінювання ефективності екологічного інвестування. Перший критерій - «дієвість», що відображає ступінь досягнення поставлених цілей, тобто характеризує результативність (effectiveness) процесу екологічного інвестування та визначається як ступінь реалізації природоохоронних заходів. Другий критерій - «ефективність» (efficiency) - це ступінь ефективності використання фінансових ресурсів на реалізацію природоохоронних заходів, визначається як співвідношення між досягнутим результатом і використаними ресурсами.

В межах кожного критерію виділено відповідні індикатори економічного розвитку, соціальної складової, екологічного стану. Слід враховувати, що методи, які доцільно використати для аналізу узгодженості елементів системи оцінювання рівня ефективності екологічного інвестування (індикаторів), для нормалізації та стандартизації даних, для визначення вагових показників та нарешті для їх агрегування в індекс ефективності екологічного інвестування не $€$ сталими і обираються під конкретні інвестиції. Для вибору показників, які потребують включення до ієрархічної системи оцінювання ефективності екологічного інвестування, враховуються відповідні фактори впливу на довкілля.

Розроблений методичний підхід до визначення ефективності екологічного інвестування базується на процесно-структурному принципі. Він відображає процес оцінювання як послідовність наступних аналітичних процедур: постановка завдань, аналіз узгодженості елементів ієрархічної системи показників, нормалізація та стандартизація вихідних показників, визначення вагових коефіцієнтів, агрегування показників за рівнями. Чітке слідування запропонованій послідовності забезпечує отримання достовірних даних, що ідентифікують ефективність екологічного інвестування. При цьому аналіз узгодженості показників дозволяє вносити необхідні зміни в набір показників [14].

Із врахуванням процесу децентралізації влади, зокрема фінансової, апробація запропонованого методичного підходу оцінювання ефективності екологічного інвестування проводилась на 
мезорівні 3 подальшим агрегуванням визначених рівнів в інтегральний індекс ефективності екологічного інвестування України. Такий підхід дозволяє діагностувати екологічну політику через оцінку рівня взаємодії між процесами інвестування та фіскальною децентралізацією та розробити заходи щодо просування екологічних технологій та коригування структури державних витрат. Отриманий загальний інтегральний показник для певної області за період відображає динаміку ефективності екологічного інвестування та дозволяє виявити чинники, що найбільше на неї впливають.

В результаті апробації запропонованого методичного підходу встановлено, що динаміка інтегрального індексу ефективності екологічного інвестування демонструє явну перевагу спадних значень інтегрального індексу ефективності екологічного інвестування над зростаючими (рис. 3).

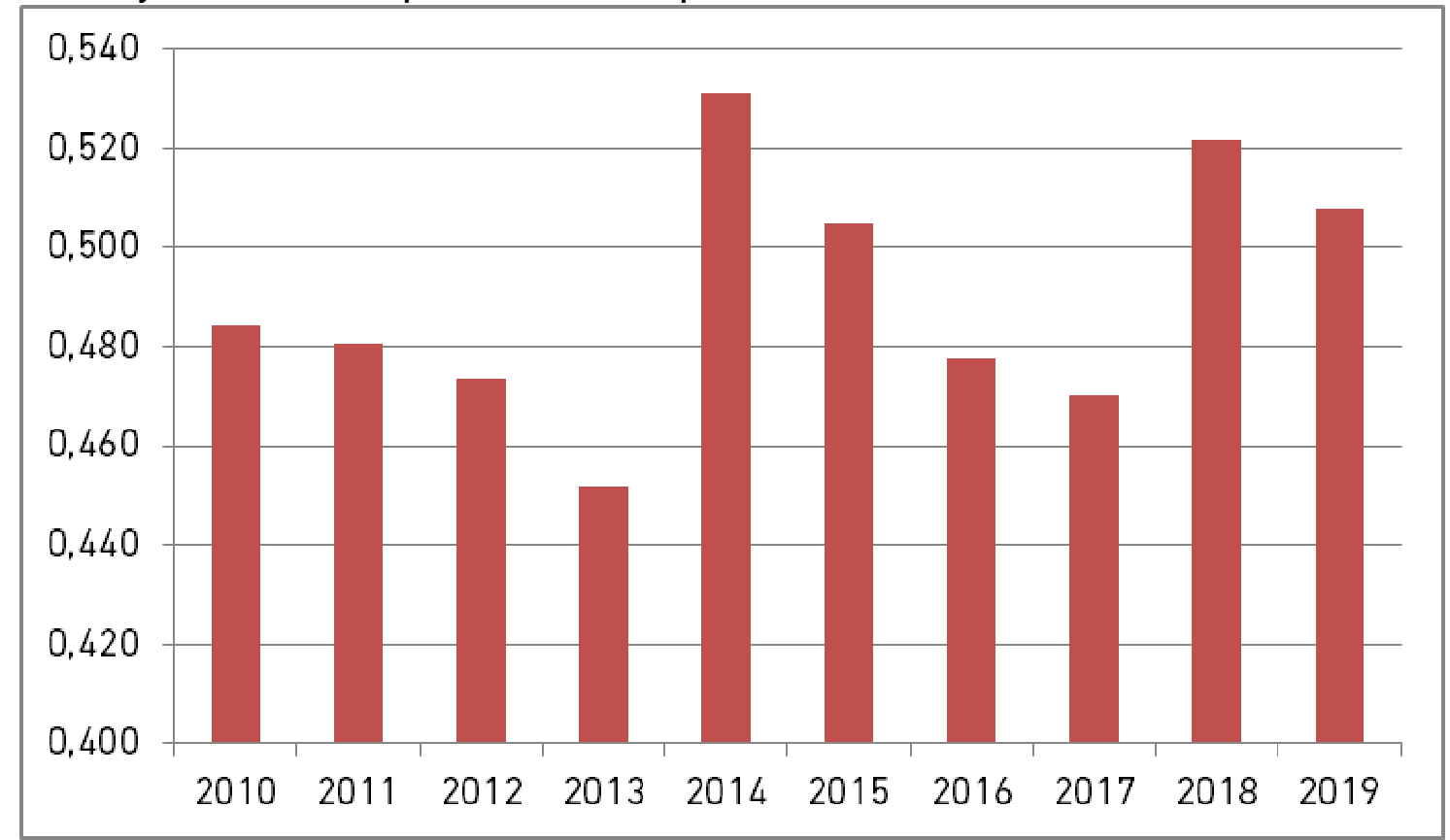

Рис. 3. Інтегральний індекс ефективності екологічного інвестування в Україні

Запропоновані концептуальні положення з оцінки ефективності екологічного інвестування передбачають інтерпретацію рівня результативності інвестування на основі бінарної моделі. Тому ефективність екологічного інвестування повинна опиратись на чітку ідентифікацію цілей та об'єктів інвестування, які є вирішальними факторами для обрання критеріїв результативності. Оптимальним критерієм буде розрахунок зміни вхідних $\left(Q_{1}\right)$ і вихідних $\left(Q_{0}\right)$ параметрів, а саму оцінку ефективності доцільно проводити за допомогою вирішення задачі бінарної класифікації на основі єдиного 
критерію ефективності екологічного інвестування $\lambda_{I-O}$ (формула 1):

$$
\lambda_{I-O}=\left\{\begin{array}{l}
1, Q_{I} \geq Q_{O} ; \\
-1, Q_{I}<Q_{O} .
\end{array}\right.
$$

На основі запропонованого підкоду та за допомогою значень інтегрального індексу нами проведено розрахунок ефективності екологічного інвестування для України в цілому та у регіональному розрізі (див. таблицю).

Таблиця

Формалізовані значення ефективності екологічного інвестування $\lambda_{I-0}$

\begin{tabular}{|c|c|c|c|c|c|c|c|c|}
\hline \multirow{2}{*}{ Регіони України } & \multicolumn{7}{|c|}{$\lambda$} \\
\cline { 2 - 9 } & 2011 & 2012 & 2013 & 2014 & 2015 & 2016 & 2017 & 2018 \\
\hline Вінницька & $-1,0$ & 1,0 & $-1,0$ & 1,0 & $-1,0$ & $-1,0$ & 1,0 & 1,0 \\
\hline Волинська & $-1,0$ & 1,0 & $-1,0$ & 1,0 & $-1,0$ & $-1,0$ & $-1,0$ & $-1,0$ \\
\hline Дніпропетровська & 1,0 & $-1,0$ & $-1,0$ & 1,0 & $-1,0$ & 1,0 & $-1,0$ & $-1,0$ \\
\hline Донецька & 1,0 & $-1,0$ & $-1,0$ & 1,0 & 1,0 & $-1,0$ & $-1,0$ & $-1,0$ \\
\hline Житомирська & 1,0 & 1,0 & 1,0 & $-1,0$ & 1,0 & $-1,0$ & 1,0 & 1,0 \\
\hline Закарпатська & 1,0 & $-1,0$ & $-1,0$ & 1,0 & 1,0 & 1,0 & $-1,0$ & $-1,0$ \\
\hline Запорізька & $-1,0$ & $-1,0$ & 1,0 & 1,0 & 1,0 & $-1,0$ & 1,0 & $-1,0$ \\
\hline Івано-Франківська & 1,0 & $-1,0$ & $-1,0$ & 1,0 & 1,0 & $-1,0$ & $-1,0$ & $-1,0$ \\
\hline Київська & 1,0 & $-1,0$ & 1,0 & 1,0 & $-1,0$ & 1,0 & $-1,0$ & $-1,0$ \\
\hline Кіровоградська & 1,0 & $-1,0$ & $-1,0$ & 1,0 & 1,0 & $-1,0$ & $-1,0$ & $-1,0$ \\
\hline Луганська & $-1,0$ & $-1,0$ & $-1,0$ & 1,0 & 1,0 & $-1,0$ & 1,0 & $-1,0$ \\
\hline Львівська & 1,0 & 1,0 & $-1,0$ & 1,0 & 1,0 & $-1,0$ & $-1,0$ & $-1,0$ \\
\hline Миколаївська & $-1,0$ & $-1,0$ & $-1,0$ & 1,0 & 1,0 & $-1,0$ & 1,0 & $-1,0$ \\
\hline Одеська & $-1,0$ & 1,0 & $-1,0$ & 1,0 & $-1,0$ & 1,0 & $-1,0$ & $-1,0$ \\
\hline Полтавська & $-1,0$ & $-1,0$ & $-1,0$ & 1,0 & 1,0 & $-1,0$ & 1,0 & $-1,0$ \\
\hline Рівненська & 1,0 & $-1,0$ & $-1,0$ & 1,0 & $-1,0$ & $-1,0$ & $-1,0$ & $-1,0$ \\
\hline Сумська & $-1,0$ & 1,0 & $-1,0$ & 1,0 & $-1,0$ & 1,0 & 1,0 & 1,0 \\
\hline Тернопільська & 1,0 & 1,0 & $-1,0$ & 1,0 & $-1,0$ & $-1,0$ & 1,0 & $-1,0$ \\
\hline Харківська & $-1,0$ & $-1,0$ & 1,0 & 1,0 & $-1,0$ & $-1,0$ & $-1,0$ & $-1,0$ \\
\hline Херсонська & 1,0 & 1,0 & $-1,0$ & 1,0 & 1,0 & 1,0 & $-1,0$ & $-1,0$ \\
\hline Хмельницька & $-1,0$ & $-1,0$ & $-1,0$ & 1,0 & $-1,0$ & $-1,0$ & 1,0 & $-1,0$ \\
\hline Черкаська & 1,0 & 1,0 & $-1,0$ & 1,0 & $-1,0$ & $-1,0$ & 1,0 & 1,0 \\
\hline Чернівецька & $-1,0$ & 1,0 & $-1,0$ & 1,0 & $-1,0$ & $-1,0$ & $-1,0$ & $-1,0$ \\
\hline Чернігівська & $-1,0$ & $-1,0$ & $-1,0$ & 1,0 & $-1,0$ & $-1,0$ & $-1,0$ & $-1,0$ \\
\hline Україна & $-1,0$ & $-1,0$ & $-1,0$ & 1,0 & $-1,0$ & $-1,0$ & $-1,0$ & 1,0 \\
\hline
\end{tabular}

Запропонований підхід до оцінювання ефективності екологічного інвестування за допомогою єдиного критерію дає однозначну оцінку щодо доцільності екологічного інвестування. Незважаючи на щорічні темпи зростання обсягів капітальних інвестицій на охорону навколишнього природного середовища та 
зменшення значень основних показників, які характеризують забруднення довкілля, формалізована ефективність екологічного інвестування в переважній більшості має негативні значення. Однією із основних причин встановленої неефективності екологічного інвестування $€$ поточна спрямованість витрат на охорону навколишнього середовища та неефективність інструментів фіскального впливу на суб'єкти господарювання.

Підсумовуючи вищесказане відмітимо, що розроблений та апробований методичний підхід до оцінювання ефективності екологічного інвестування, на противагу існуючим, у реаліях сьогодення дозволяє комплексно і системно підходити до оцінювання ефективності інвестиційної діяльності у сфері охорони навколишнього природного середовища, а також дозволяє ідентифікувати причинно-наслідкові зв'язки та ухвалювати обґрунтовані управлінські рішення 3 метою удосконалення використання фінансових ресурсів природоохоронного призначення.

1. Аналіз дефініційної основи терміна «екологічні (зелені) інвестиції» та їх класифікація / Ігнатченко А. С. та ін. 2020. 2. Чигрин О. Ю., Красняк В. С. Теоретикоприкладні аспекти розвитку екологічного інвестування в Україні. 2015. 3. Тихенко В. С. Екологічні інвестиції в Україні: теоретично-прикладний аспект. Вісник Дніпропетровського університету. Сер. Економіка. 2013. № 21. Вип. 7 (4). С. $47-$ 52. 4. Варламова І. С. Особливості екологічного інвестування в національній економіці. Інноваційна економіка. 2016. № 1-2. С. 158-162. 5. Квактун 0. О. Реальні екологічні інвестиції як дієвий інструмент сталого проектування та будівництва регіонів України. Економічний простір. 2014. № 83. С. 68-77. 6. Скрипчук П. М., Строченко Н. І., Вега А. Ю. Соціо-еколого-економічні засади природокористування: інновації, інвестиції та механізм реалізації. 2014. 7. Латишева О. В. Екологічні інвестиції: сучасний стан та перспективи їх впровадження в Україні для забезпечення сталого розвитку держави. Экономический вестник Донбасса. 2018. № 1 (51). 8. Голян В. Інвестиції в екологію: джерела, форми та резерви нарощення. Економіст. 2015. № 8. С. 7-11. 9. Петренко І. П. Екологічні інвестиції та джерела їх фінансування в Україні. Науковий вісник Міжнародного гуманітарного університету. Сер. Економіка і менеджмент. 2018. № 32. С. 62-68. 10. Ліпич Л., Глубіцька Т. Оцінка ефективності вкладення інвестицій в екологічні проекти за синергетичним ефектом. Економічний часопис Східноєвропейського національного університету імені Лесі Українки. 2015. № 3. С. 28-34. 11. Швець В. Я., Роздобудько Е. В., Соломіна Г. В. Агрегована методика багатокритеріальної економіко-екологічної експертизи екологоорієнтованих інвестиційних проектів. Науковий вісник Національного гірничого університету. 2013. № 3. С. 139-144. 12. Ковшун Н. Е., П'ятка Н. С. Екологічні інвестиції: сутність та види. Вісник Одеського національного університету. Сер. Економіка. 2018. № 23. Вип. 8. С. 170-174. 13. Варламова С. І., Драган І. В. Інвестиційне забезпечення екологічних проектів суб'єктів господарювання. Агросвіт. 2019. № 5. С. 41-46. 14. П'ятка Н. С. Методологія оцінювання економічної ефективності екологічного інвестування. Вісник Національного університету водного господарства та природокористування. Сер. Економічні науки. 2019. Вип. 4 (88). C. 235-247. 
Серія «Економічні науки»

Випуск 3(95) 2021 р.

\section{REFERENCES:}

1. Analiz definitsiinoi osnovy termina «ekolohichni (zeleni) investytsii» ta yikh klasyfikatsiia / Ihnatchenko A. S. ta in. 2020. 2. Chyhryn O. Yu., Krasniak V. S. Teoretyko-prykladni aspekty rozvytku ekolohichnoho investuvannia v Ukraini. 2015. 3. Tykhenko V. S. Ekolohichni investytsii v Ukraini: teoretychno-prykladnyi aspekt. Visnyk Dnipropetrovskoho universytetu. Ser. Ekonomika. 2013. № 21. Vyp. 7 (4). S. 4752. 4. Varlamova I. S. Osoblyvosti ekolohichnoho investuvannia v natsionalnii ekonomitsi. Innovatsiina ekonomika. 2016. № 1-2. S. 158-162. 5. Kvaktun 0. 0. Realni ekolohichni investytsii yak diievyi instrument staloho proektuvannia ta budivnytstva rehioniv Ukrainy. Ekonomichnyi prostir. 2014. № 83. S. 68-77. 6. Skrypchuk P. M., Strochenko N. I., Veha A. Yu. Sotsio-ekoloho-ekonomichni zasady pryrodokorystuvannia: innovatsii, investytsii ta mekhanizm realizatsii. 2014. 7. Latysheva 0. V. Ekolohichni investytsii: suchasnyi stan ta perspektyvy yikh vprovadzhennia $v$ Ukraini dlia zabezpechennia staloho rozvytku derzhavy. Ekonomicheskiy vestnik Donbassa. 2018. № 1 (51). 8. Holian V. Investytsii v ekolohiiu: dzherela, formy ta rezervy naroshchennia. Ekonomist. 2015. № 8. S. 7-11. 9. Petrenko I. P. Ekolohichni investytsii ta dzherela yikh finansuvannia v Ukraini. Naukovyi visnyk Mizhnarodnoho humanitarnoho universytetu. Ser. Ekonomika i menedzhment. 2018. № 32. S. 62-68. 10. Lipych L., Hlubitska T. Otsinka efektyvnosti vkladennia investytsii v ekolohichni proekty za synerhetychnym efektom. Ekonomichnyi chasopys Skhidnoievropeiskoho natsionalnoho universytetu imeni Lesi Ukrainky. 2015. № 3. S. 28-34. 11. Shvets V. Ya., Rozdobudko E. V., Solomina H. V. Ahrehovana metodyka bahatokryterialnoi ekonomiko-ekolohichnoi ekspertyzy ekolohooriientovanykh investytsiinykh proektiv. Naukovyi visnyk Natsionalnoho hirnychoho universytetu. 2013. № 3. S. 139-144. 12. Kovshun N. E., Piatka N. S. Ekolohichni investytsii: sutnist ta vydy. Visnyk Odeskoho natsionalnoho universytetu. Ser. Ekonomika. 2018. № 23. Vyp. 8. S. 170-174. 13. Varlamova S. I., Drahan I. V. Investytsiine zabezpechennia ekolohichnykh proektiv subiektiv hospodariuvannia. Ahrosvit. 2019. № 5. S. 41-46. 14. Piatka N. S. Metodolohiia otsiniuvannia ekonomichnoi efektyvnosti ekolohichnoho investuvannia. Visnyk Natsionalnoho universytetu vodnoho hospodarstva ta pryrodokorystuvannia. Ser. Ekonomichni nauky. 2019. Vyp. 4 (88). S. 235-247.

Kovshun N. E. [1; ORCID ID: 0000-0003-0573-2932], Doctor of Economics, Professor,

Piatka N. S. [2; ORCID ID: 0000-0001-9810-3961], Candidate of Economics (Ph.D.), Senior Lecturer, Zhydyk I. A. [1; ORCID: 0000-0002-8438-9708] Deputy Director of the Institute of Institute of Postgraduate Education of NUWEE for Educational and Methodological Work

${ }^{1}$ National University of Water and Environmental Engineering, Rivne

${ }^{2}$ Mukachevo State University, Mukachevo

\section{EFFICIENCY OF ENVIRONMENTAL INVESTMENT IN UKRAINE}

The article defines the content of environmental investments and highlights their characteristics. Taking into account the main directions of 
ecological investment, the semantic model of interaction of its objects and subjects is presented.

The results of the research of the main directions of financing of nature protection activity in Ukraine are presented. The tendencies of change of nominal and real volumes of capital investments in environmental protection are established. A retrospective study of their components was conducted. The level of investment support for environmental protection in Ukraine is considered low. the volume of investments in integrated technologies does not contribute to the formation of the resource base for modernization, reconstruction, and technical re-equipment of environmental infrastructure. The identified limited sources of funding are caused by excessive statehood and centralization of the environmental management system. The urgency of the problem of adequate assessment of the feasibility and effectiveness of environmental investments is shown.

Taking into account the scientific developments of international organizations and the world's leading think tanks, proposals have been developed on methods for assessing the effectiveness of environmental investments. The stages and levels of such assessment are highlighted. As a result of approbation of the offered methodological approach, the dynamics of the integrated indicator of the efficiency of ecological investments in Ukraine as a whole and a regional context is established. There is an annual increase in capital investment in environmental protection and a decrease in the values of key indicators that characterize environmental pollution. But the formalized efficiency of environmental investment in the vast majority is negative

Keywords: ecological investments; efficiency; financing of ecological investments; efficiency criterion; methodical approach; integrated indicator; Ukraine.

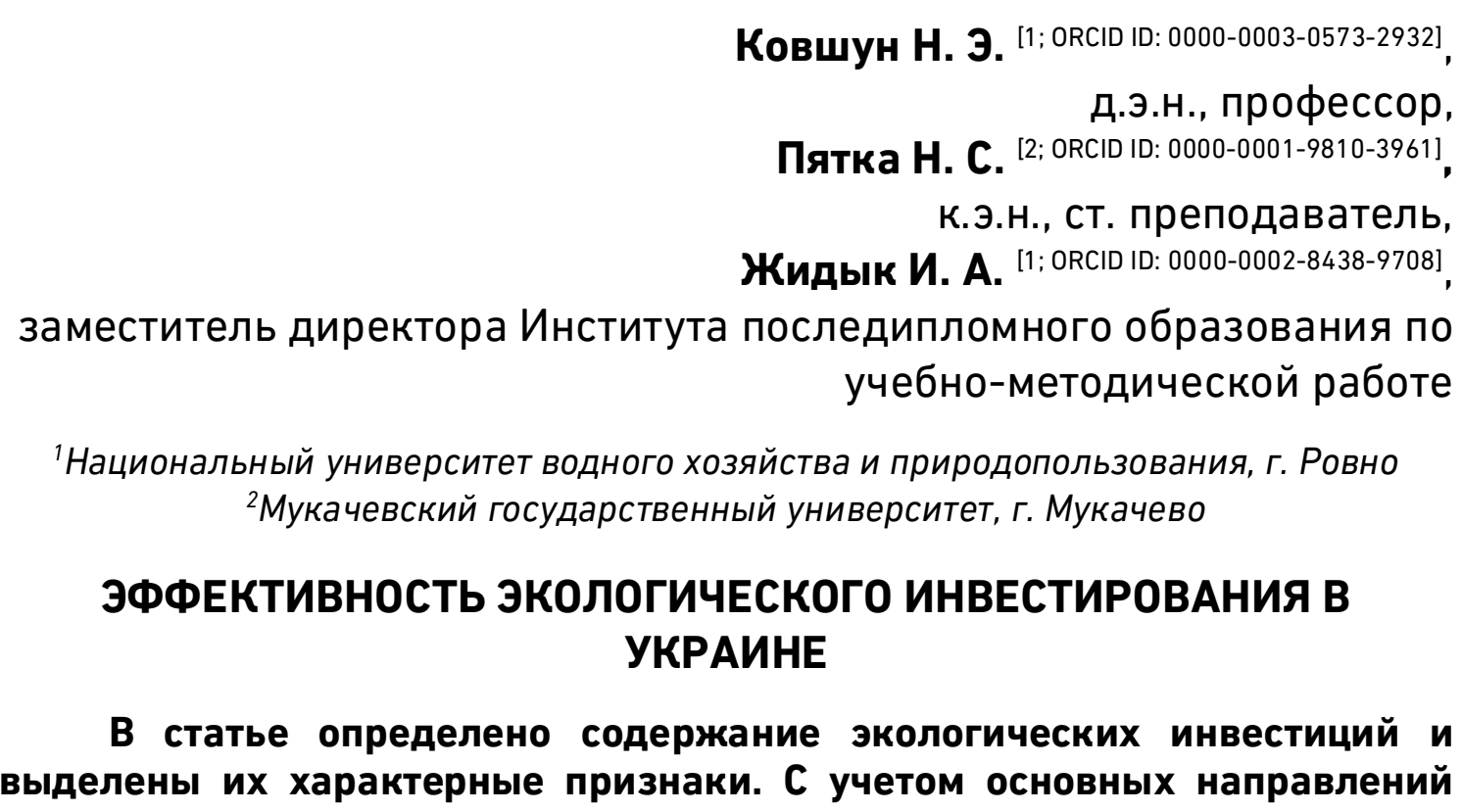



субъектами.

Представлены результаты исследования основных направлений финансирования природоохранной деятельности в Украине. Установлено тренды изменения номинального и реального объемов капитальных инвестиций в охрану окружающей среды. Проведено ретроспективное исследование их составляющих. Уровень инвестиционного обеспечения охраны окружающей среды в Украине признано недостаточным.

Показана актуальность проблемы адекватной оценки целесообразности и эффективности экологических инвестиций. С учетом научных разработок международных организаций и ведущих аналитических центров мира, разработаны предложения по методике оценки эффективности экологического инвестирования. Выделены этапы и уровни такой оценки. В результате апробации предложенного методического подхода установлено динамику интегрального индекса эффективности экологического инвестирования в Украине в целом и в региональном разрезе.

Ключевые слова: экологические инвестиции; эффективность; финансирование экологических инвестиций; критерий эффективности; методический подход; интегральный показатель; Украина.

Отримано: 03 вересня 2021 р. Прорецензовано: 08 вересня 2021 р. Прийнято до друку: 24 вересня 2021 р. 